\title{
Hepatitis C Virus Outbreaks in Hemodialysis Centers: A Continuing Problem
}

\author{
David J. Weber, MD, MPH; ${ }^{1,2}$ William A. Rutala, $\mathrm{PhD}, \mathrm{MPH} ;{ }^{1,2}$ Michael W. Fried, $\mathrm{MD}^{3}$
}

(See the articles by Nguyen et al, on pp. 125-133, and by Aho et al, on pp. 134-139.)

The Centers for Disease Control and Prevention (CDC) estimates that $\sim 370,000$ people in the United States rely on hemodialysis care. ${ }^{1}$ Despite the publication of multiple guidelines over the years, acquisition of hepatitis $\mathrm{C}$ virus (HCV) continues to occur in dialysis centers. In this commentary, we review recent outbreaks of hepatitis $\mathrm{C}$ in hemodialysis centers and describe the breach of infection control policies and procedures that were incriminated in these outbreaks.

The reasons for continued outbreaks of HCV in dialysis centers may be examined by reviewing the following factors: (1) characteristics of HCV including prevalence, transmissibility, and environmental stability; (2) the physical layout of dialysis centers; (3) patient risk factors; and (4) failure of healthcare personnel (HCP) to adhere to standards of infection control.

\section{FEATURES OF HCV THAT FAVOR}

TRANSMISSION IN DIALYSIS CENTERS

Several features of HCV enhance the risk of transmission in hemodialysis centers: (1) HCV infection is common in the United States. (2) HCV is transmissible via needle sticks and other parenteral exposures. (3) HCV is stable in the environment for days to weeks. (4) Most patients with HCV are asymptomatic. The CDC estimates that there are 2.7 million persons with chronic HCV infection in the United States. ${ }^{2}$ Transmission routes for HCV include infection drug use, needle-stick injuries in healthcare, sharing personal items contaminated with infectious blood (eg, razors), and other healthcare procedures that involve invasive procedures such as injections. The risk of transmission via a parenteral exposure such as a needle stick is between $1 \%$ and $2 \% .^{3}$ A meta-analysis reported the rate or transmission by needle sticks as $1.9 \%{ }^{4}$ Various studies have reported that HCV inoculated onto surfaces survived at room temperature for up to 16 hours, ${ }^{5}$ up to 5 days, ${ }^{6}$ and up to 6 weeks. ${ }^{7} \mathrm{HCV}$ survived in tuberculin syringes for up to 63 days. $^{8}$ Importantly, $\sim 70 \%-80 \%$ of patients with $\mathrm{HCV}$ are asymptomatic., ${ }^{2,3}$ Thus, infection can only be detected via diagnostic tests. Failure to obtain HCV testing to identify infected persons may lead to decreased attention to infection control in infected persons.

\section{CHARACTERISTICS OF DIALYSIS CENTERS THAT ENHANCE THE POSSIBILITY OF HCV TRANSMISSION}

A number of characteristics of hemodialysis centers and the process of dialysis enhance the possibility of HCV transmission. (1) Patients are generally placed in bays separated from other patients by a short distance. (2) Sinks may not be available in each bay. (3) HCP have frequent contact with bloodcontaining devices. (4) Facilities may lack separate clean and dirty utility rooms or a separate medication preparation area. (5) Dialysis centers are usually free standing and do not have immediate access to trained infection control preventionists. (6) Dialysis machines and equipment are heavily blood contaminated and must be disinfected with strict adherence to manufacturer's recommendations and sterilization/ disinfection guidelines.

\section{PATIENT CHARACTERISTICS THAT PROMOTE TRANSMISSION OF HCV}

Several patient characteristics promote transmission of HCV: (1) Dialysis is prolonged and patients require venous access. (2) Patients frequently receive medications via injection or infusion. (3) Patients may be unable to fully participate in their care.

\section{INFECTION CONTROL IN HEMODIALYSIS CENTERS}

Multiple studies have demonstrated that HCP in dialysis centers are often poorly compliant with infection guidelines to prevent $\mathrm{HCV}$ transmission in these settings. ${ }^{9,10}$ Shimokura et $\mathrm{al}^{9}$ used a cluster random survey design to study HCP in

Affiliations: 1. Department of Hospital Epidemiology, University of North Carolina Health Care, Chapel Hill, NC; 2. Division of Infectious Diseases, UNC School of Medicine, Chapel Hill, NC; 3. Division of Gastroenterology, UNC School of Medicine, Chapel Hill, NC.

Received November 1, 2015; accepted November 3, 2015 
тABLE 1. Selected Recent Clusters of Hepatitis C Virus in Hemodialysis Centers, 2005-2015

\begin{tabular}{|c|c|c|c|c|}
\hline Author, Year & Country & $\begin{array}{l}\text { No. of } \\
\text { Cases }^{\text {a }}\end{array}$ & $\begin{array}{l}\text { Molecular } \\
\text { Analysis }\end{array}$ & Potential Breaches Identified \\
\hline Savey, $2005^{11}$ & France & 22 & Yes & $\begin{array}{l}\text { Lack of adequate space between bays; lack of space for preparing infusions and injections; } \\
\text { low nurse-to-patient ratio; inadequate training of staff; noncompliance with } \mathrm{HH} \text { and } \\
\text { proper glove use; sharing of equipment among patients (eg, scissors); lack of routine } \\
\text { surface decontamination }\end{array}$ \\
\hline Kondili, $2006^{12}$ & Italy & 4 & Yes & Use of multidose vials of heparin \\
\hline Lanini, $2010^{15}$ & Italy & 13 & Yes & $\begin{array}{l}\text { Source likely contamination of a multidose heparin via use of multidose vials of saline; } \\
\text { poor compliance with } \mathrm{HH} \text {; failure to change gloves between patients }\end{array}$ \\
\hline Roy, $2012^{16}$ & Spain & 2 & Yes & $\begin{array}{l}\text { Poor compliance with } \mathrm{HH} \text { and glove use; multidose heparin vials; lack of adequate space } \\
\text { between dialysis bays; source likely an infected HCP }\end{array}$ \\
\hline Nguyen, $2015^{19}$ & $\begin{array}{l}\text { United } \\
\text { States }\end{array}$ & 18 & Yes & $\begin{array}{l}\text { Poor compliance with } \mathrm{HH}(82 \%) \text {; failure to change gloves between machines; clinic did } \\
\text { not clearly label clean and dirty sinks; failure to disinfect hubs and vial tops; } \\
\text { medication preparation next to a sink; failure to maintain asepsis when accessing } \\
\text { vascular devices; ineffective surface disinfection; failure to disinfect priming buckets }\end{array}$ \\
\hline Aho, $2015^{20}$ & France & 1 & Yes & $\begin{array}{l}\text { Transmission felt due to failure to perform } \mathrm{HH} \text { and/or transmission by instruments (eg, } \\
\text { scissors, clamps, etc.) }\end{array}$ \\
\hline
\end{tabular}

NOTE. HCP, healthcare provider; HCV, hepatitis C virus; $\mathrm{HH}$, hand hygiene.

${ }^{a}$ Cases may have been distributed among multiple clusters as identified by molecular analysis; not all patients identified may have been linked to the outbreak(s).

53 hemodialysis facilities in the United States in 2000. Only $57 \%$ of these facilities reported that HCP always performed hand hygiene $(\mathrm{HH})$ and changed gloves before putting patients on dialysis; $47 \%$ reported that $\mathrm{HCP}$ performed $\mathrm{HH}$ between patient care stations; and 55\% reported that HCP performed $\mathrm{HH}$ between patients when administering intravenous medications, ${ }^{9}$ In a more detailed analysis, Shimokura et $\mathrm{al}^{10}$ reported that the patient care practices independently associated with a higher center prevalence of HCV included reusing priming receptacles without disinfection (odds ratio [OR], 2.3), handling blood specimens adjacent to medications and clean supplies (OR, 2.2), and using mobile carts to deliver injectable medications $(\mathrm{OR}, 1.7)$. Independently related facility covariates were $\geq 10 \%$ patient $\mathrm{HCV}$ prevalence (OR, 3.0), patient-to-staff ratio $>7$ to 1 (OR, 2.4), and treatment duration $\geq 2$ years (OR, 2.4).

\section{LESSONS FROM OUTBREAKS OF HCV IN HEMODIALYSIS CENTERS}

Outbreaks of HCV in hemodialysis centers continue to be reported (Table 1). ${ }^{1-20}$ The papers in this issue by Nguyen et $\mathrm{al}^{19}$ and Aho et $\mathrm{al}^{20}$ add to the growing body of knowledge regarding the breaches in infection control practices that lead to HCV outbreaks. Most clusters of HCV were associated with multiple breaches in infection control practices. The potential breaches described in these outbreaks demonstrate the following common themes: (1) use of multidose vials generally for heparin or saline administration; (2) poor compliance with hand hygiene before and after each patient contact or after touching a possibly contaminated surface; (3) failure to change gloves when moving between patients or between patients and potentially contaminated surfaces; (4) failure to adequately disinfect environmental surfaces; (5) unsafe injection practices; (6) failure to disinfect shared equipment between patient uses; (6) lack of a separate area for medication preparation; and (7) failure to have clearly separated clean and dirty utility rooms. Reviews of outbreak investigations between 1998 and 2008 revealed similar deficiencies in infection control practices. ${ }^{21}$

These outbreaks also demonstrate the importance of using molecular methods in outbreak investigations of HCV outbreaks related to dialysis. In many cases, multiple small clusters were demonstrated rather than a single large clonal cluster.

\section{PREVENTING HCV TRANSMISSION DURING DIA LYS IS}

Detailed recommendations are available from the CDC for preventing the transmission of infections among chronic 
hemodialysis patients; ${ }^{22}$ they have been updated by the CDC to clarify guidance on parenteral medical vial. ${ }^{23}$ Strict adherence to these guidelines should prevent person-to-person transmission of HCV in hemodialysis centers. Furthermore, recent advances in therapy for hepatitis $\mathrm{C}$ have demonstrated that direct acting antiviral regimens are safe and highly effective for treating $\mathrm{HCV}$-infected patients on hemodialysis. ${ }^{24}$ Thus, screening and identification of HCV in hemodialysis patients with consideration for treatment could further decrease the risk of transmission within dialysis units.

\section{ACKNOWLEDGMENTS}

Financial support. No financial support was provided relevant to this article.

Potential conflicts of interest. All authors report no conflicts of interest relevant to this article.

Address correspondence to David J. Weber, MD, MPH, 2163 Bioinformatics, CB \#7030, Chapel Hill, NC, 27599-7030 (dweber@unch.unc.edu).

\section{REFERENCES}

1. Clinician Education-Dialysis safety. Centers for Disease Control and Prevention website. http://www.cdc.gov/dialysis/clinician/ index.html. Accessed October 29, 2015.

2. Viral hepatitis-hepatitis information. Centers for Disease Control and Prevention website. http://www.cdc.gov/hepatitis/hcv/ hcvfaq.htm\#section1. Accessed October 29, 2015.

3. Pozzetto B, Memmi M, Garraud O, Roblin X, Berthelot P. Health care-associated hepatitis $\mathrm{C}$ virus infection. World J Gastroenterol 2014;20:17265-17278.

4. Henderson DK. Managing occupational risks for hepatitis C transmission in the health care setting. Clin Microbiol Rev 2003;16:546-568.

5. Kamili S, Krawczynski K, McCaustland K, Li X, Alter MJ. Infectivity of hepatitis $\mathrm{C}$ virus in plasma after drying and storing at room temperature. Infect Control Hosp Epidemiol 2007;28:519-524.

6. Doerrbecker J, Friesland M, Ciesek $S$, et al. Inactivation and survival of hepatitis C virus on inanimate surfaces. J Infect Dis 2011;204:1830-1838.

7. Paintsil E, Binka M, Patel A, Lindenbach BD, Heimer R. Hepatitis $\mathrm{C}$ virus maintains infectivity for weeks after drying on inanimate surfaces at room temperature: implications for risks of transmission. J Infect Dis 2014;209:1205-1211.

8. Paintsil E, He H, Peters C, Lindenbach BD, Heimer R. Survival of hepatitis $\mathrm{C}$ virus in syringes: implications for transmission among injection drug users. J Infect Dis 2010;202:984-990.

9. Shimokura G, Weber DJ, Miller WC, Wurtzel H, Alter MJ. Factors associated with personal protection equipment use and hand hygiene among hemodialysis staff. Am J Infect Control 2006;34:100-107.

10. Shimokura G, Chai F, Weber DJ, et al. Patient-care practices associated with an increased prevalence of hepatitis $\mathrm{C}$ virus infection among chronic hemodialysis patients. Infect Control Hosp Epidemiol 2011;32:415-424.

11. Savey A, Simon F, Izopet J, Lepoutre A, Fabry J, Desenclos J-C. A large nosocomial outbreak of hepatitis C infections at a hemodialysis center. Infect Control Hosp Epidemiol 2005;26: 752-760.

12. Kondili LA, Genovese D, Argentini C, et al. Nosocomial transmission in simultaneous outbreaks of hepatitis $\mathrm{C}$ and $\mathrm{B}$ virus infections in a hemodialysis center. Eur J Clin Microbiol Infect Dis 2006;25:527-531.

13. Spada E, Abbate I, Sicurezza E, et al. Molecular epidemiology of a hepatitis $\mathrm{C}$ virus outbreak in hemodialysis unit in Italy. $J$ Med Virol 2008;80:261-267.

14. Centers for Disease Control and Prevention. Hepatitis C virus transmission at an outpatient hemodialysis unit-New York, 2001-2008. MMWR 2009;58:189-194.

15. Lanini S, Abbate I, Puro V, et al. Molecular epidemiology of a hepatitis $\mathrm{C}$ virus epidemic in haemodialysis unit: outbreak investigation and infection outcome. BMC Infect Dis 2010;10:257.

16. Roy KM, Galmes-Truyols A, Gimenez-Duran J, et al. Epidemiology and molecular investigation of hepatitis C infection following holiday haemodialysis. J Hosp Infect 2012;82: 158-163.

17. Szucs M, Dencs A, Varga E, et al. An archived serum sample as a clue for identifying the primary source of a nosocomial hepatitis C virus outbreak in a haemodialysis center. Arch Virol 2014;59:2207-2212.

18. Rao A, Luckman E, Wise ME, et al. Outbreak of hepatitis C virus infections at an outpatient hemodialysis facility: the importance of infection control competencies. Nephrol Nurs J 2013;40: 101-110.

19. Nguyen DB, Gutowski J, Ghiselli M, et al. A large outbreak of hepatitis $\mathrm{C}$ virus infections in a hemodialysis clinic. Infect Control Hosp Epidemiol 2016;37:125-133.

20. Aho L-S, Giraudon H, Astruc K, et al. Investigation of a case of $5 \mathrm{a}-\mathrm{HCV}$ transmission in a hemodialysis unit using epidemiological data and deep sequencing. Infect Control Hosp Epidemiol 2016;37:134-139.

21. Patel PR, Thompson ND, Kallen AJ, Arduino MJ. Epidemiology, surveillance, and prevention of hepatitis $C$ virus infections in hemodialysis patients. Am J Kidney Dis 2010;56:371-378.

22. Centers for Disease Control and Prevention. Recommendations for preventing transmission of infections among chronic hemodialysis patients. MMWR 2001;50:1-43.

23. Centers for Disease Control and Prevention. Infection control requirements for dialysis facilities and clarification regarding guidance on parenteral medical vials. $M M W R$ 2008;57:875-876.

24. Roth D, Nelson DR, Bruchfeld A, et al. Grazoprevir plus elbasvir in treatment-naive and treatment-experienced patients with hepatitis $C$ virus genotype 1 infection and stage 4-5 chronic kidney disease (the C-SURFER study): a combination phase 3 study. Lancet 2015;386:1537-1545. 